\section{A Seasonality}

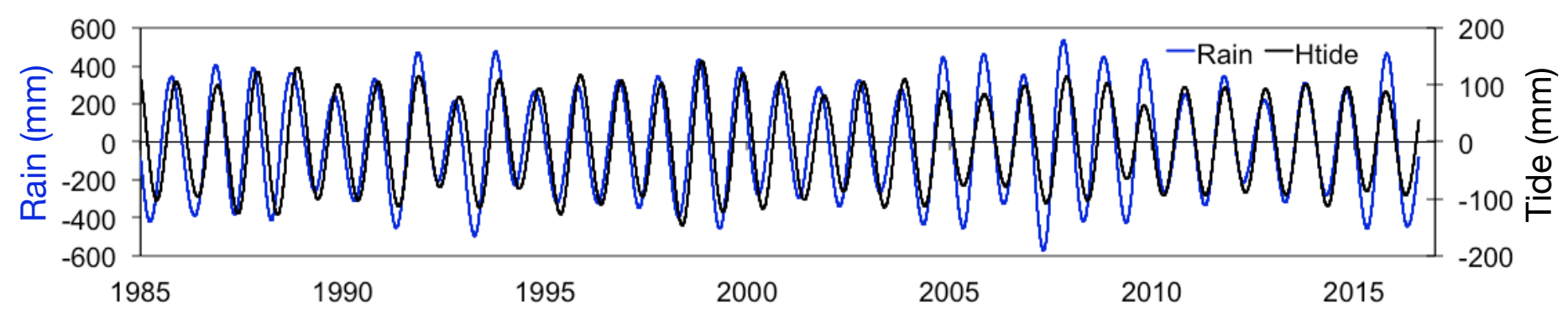

\section{B Long-term}

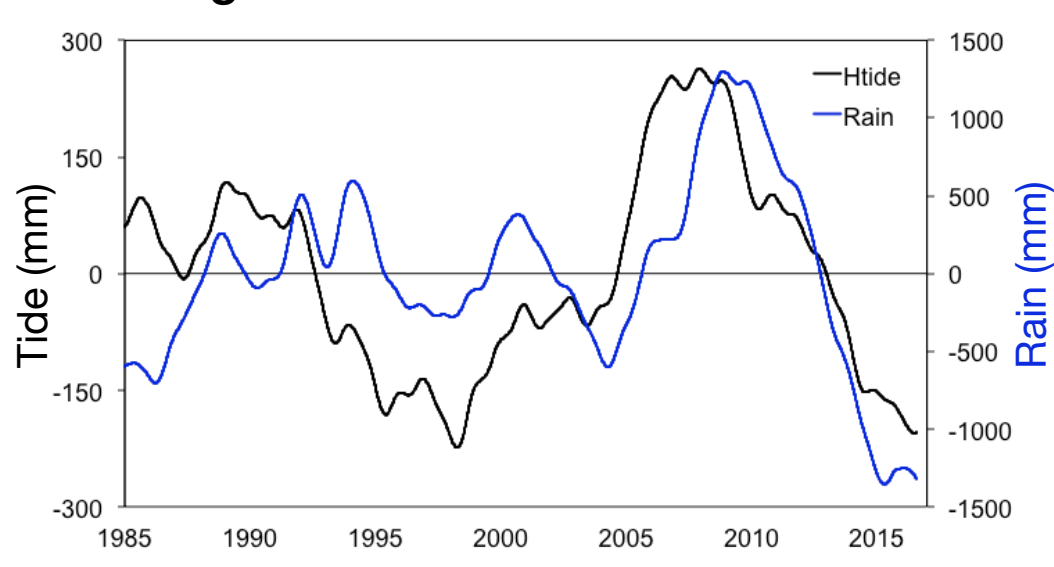

